\title{
Cell Fate Control
}

National Cancer Institute

\section{Source}

National Cancer Institute. Cell Fate Control. NCI Thesaurus. Code C26142.

Cell Fate Control involves intercellular, cellular, and intracellular processes that regulate the generally irreversible commitment of a multipotent cell(s) to a specific ensuing cell development lineage among alternate potential lineage options. 